International Journal of Humanities and Social Sciences p-ISSN: 1694-2620 | e-ISSN: 1694-2639

Vol. 13, No. 2 (2021), pp. 76-90, (IJHSS https://doi.org/10.26803/ijhss.13.2.5

Received June 14, 2021 | Revised September 30, 2021 | Accepted October 25, 2021

\title{
Psychological Distress and Work Engagement among The Faculty Members on University of Batangas: Basis for the Formulation of a Program Involving Mental Health
}

\author{
Diane D. Lipat, RPm, MA Psy, CMHFR \\ Mahjalin Bugtong- Diez, RPsy, RPm, MS Clinical Psy, CMHFR \\ Daniel Deleniana, LPT \\ Berlinda Perez, LPT \\ Anna Marie Orig \\ University of Batangas, \\ Batangas Campus, Philippines
}

\begin{abstract}
This is a descriptive-comparative study which aimed to measure the level of work engagement and psychological distress of faculty members. Just as students need support to continue learning, teachers need support to continue teaching. With teachers engaging in a multitude of tasks and their responsibilities not limited to preparing and discussing lessons alone, they are becoming more prone to experiencing higher levels of psychological distress. This can then impact their work engagement and their ability to function effectively. In consideration of this, this study attempted to assess the psychological distress and work engagement of selected faculty members at the University of Batangas (UB) Main Campus. Specifically, this study measured gender differences in terms of psychological distress and work engagement. In addition, the focus of this study also included determining whether a significant relationship exists between teachers' psychological distress and work engagement through the adapted and self-constructed questionnaire. Results showed that selected teachers from the UB exhibited mild forms of psychological distress but high levels of work engagement. No significant differences in psychological distress and work engagement were found between male and female teachers. A mental health program was also proposed as an output of the study to help combat psychological distress and improve work engagement among teachers.
\end{abstract}

Keywords: mental health; psychological distress; work engagement

\section{Introduction}

Teaching is not an easy job. It is not confined to being in the classroom, teaching the lesson for the day, evaluating examinations or activities, and giving grades to students. The teaching profession has evolved from a mere boxed definition to a continuously varying profession. Added responsibilities and other work are expected of every teacher 
daily as part of their profession. Aside from that, times have changed and educational methods and techniques have to be continually upgraded to cater to a changing society and changed studentry. It is therefore imperative that teachers must have a good quality of teaching and sufficient talent, not only in their subject matter but also in other areas of interest to attract students in general. Also, work overload and low salaries can also influence the level of psychological distress a teacher experiences. Considering all these factors, it cannot be denied that teaching as a job comes along with stressors that could impact the teachers themselves.

Clipa (2017) states that there are varieties of professions across the country but teaching is different from the rest. It was mentioned that it is the duty of every teacher to learn many more skills for their effective teaching. Students nowadays are clever and teachers must enter the classroom knowledgeable enough to answer all student queries. This is the reason why teachers need to have sufficient expertise on their subject matter and in all areas that concern the students to ensure the effective learning of students. Apart from this, teachers also need to deal with workloads and low salaries. These have become a challenge for teachers to balance their personal and professional lives and handle all the stressors one at a time.

Psychological distress is a general term that is used to describe unpleasant feelings or emotions that impact one's level of functioning and is operationally defined as the negative feelings of stress, pressure, and frustration at work. On the other hand, work engagement can be defined as a positive, fulfilling, work-related state of mind that is characterized by vigor, dedication, and absorption and can be easily understood as how workers experience their work: as stimulating and energetic and something to which they want to devote time and effort (Viertiö, et.al, 2021).

Somehow also, because teachers are dealing with a high number of roles and obligations, and a large number of them are stressed, Tan (2017) was able to relate that it was the cause for some of them to be anxious and depressed. He further mentioned that aside from teaching and advising students, preparing papers and lectures for class and assemblies for research, additional work in the department and other things such as daily family affairs, social functions and obligations add stress to a college teacher. However, stress and all its forms can also be due to societal expectations and how the teachers meet them (Pagayanan \& Ed, 2016).

It was even attested by Clipa (2017) that stress from teaching runs far deeper than that of any other profession because of its high score in terms of occupational stress. In addition, according to Tan (2017), teachers are dealing with numerous roles and obligations, and a large number of them are stressed. This is the primary reason that this study focuses on the college instructors at the UB, both full time and part-time, and who are handling both major and general education subjects.

It is important to understand the different sources of employee/faculty's psychological stress. Psychological distress can be defined as a typically negative response to a stressor and usually has accompanying anxiety, concern, and a decrease in performance. It is something that may lead to other serious problems if not given proper and immediate attention: that is why it is important to consider the various factors that affect the mental health of a person. Furthermore, this distress can hinder a person's different areas of functioning such as performing work-related task and fulfilling other daily obligations (Viertio et al., 2021). 
The researchers were guided by the following objectives, namely to measure the level of psychological distress of selected faculty members in the UB, to measure the level of work engagement of selected faculty members in the UB, to measure the significant relationship between psychological distress and work engagement among selected faculty members in the UB, to measure the significant difference in the level of psychological distress among selected faculty members in the UB in terms of their gender and to formulate a mental health program which will help curb psychological distress and promote work engagement and mental health in general.

\section{Method}

\section{Participants}

Data were gathered from fifty UB faculty members $(\mathrm{N}=50)$. Of these, $50 \%$ were males and $50 \%$ were females, ensuring that both men and women were equally represented in the study. Sampling was carried out using random sampling. Inclusion criteria are faculty members who have worked for a minimum of one year in the university and faculty members who are full-time workers.

\section{Design}

Descriptive correlational and comparative research designs were utilized to identify the relationship between teachers' levels of psychological distress and work engagement, and the difference in their levels of psychological distress in terms of their gender.

\section{Materials}

Respondents' levels of psychological distress were measured using a validated selfconstructed questionnaire. For scoring purposes, the higher the mean obtained in this questionnaire, the higher the level of psychological distress. Specifically, a mean ranging from 1.00-2.00 signifies no distress, a mean of 2.01.-3.00 indicates a mild level of psychological distress, a mean of $3.01-4.00$ is indicative of a moderate level of psychological distress while a mean of 4.01 - 5.00 signifies a severe level of psychological distress.

The other one is an adapted standardized instrument named Utrecht Work Engagement Scale (UWES) that will help measure the work engagement of the subjects of this study. Both tests underwent pilot testing, to determine whether kit is applicable in measuring the variables of the study. It has high internal consistency with Cronbach's $\alpha$ coefficient values of $0.867,0.819$, and 0.903 for three sub scales and test retest reliability was high $(\mathrm{p}<0.001)$.

\section{Procedure}

There were ethical concerns and considerations in conducting the study. The initial concern was regarding the consent and the participation of the respondents: the ethics committee deemed that the employees may opt not to cooperate because the study and the result may somehow reflect on the image of the institution. Concerns about the formulation of the questions were also raised since some questions may be worded as a violation of the respondents' personal lives. With the input of the research and ethics committee, the concerns were answered and the research was approved. It also underwent evaluation by and gained the approval of the research and ethics committee.

As the research work progressed, data were gathered using two separate instruments. One is a validated self-constructed questionnaire that measured psychological distress. The self-constructed questionnaire was created in the Philippine context as suggested by 
the experts to apply to the psychological distress as experienced by Filipino teachers. Items constructed were validated by registered psychologists and psychometricians and were then pilot tested. Data from the newly constructed instrument entitled the Psychological Distress Scale demonstrated an acceptable estimate of internal consistency. For instance, the variable, psychological distress, yielded an acceptable alpha coefficient ( $\alpha=0.782$ ). In this current paper, use was made of a total of 15 respondents for pilot testing. As a rule of thumb when estimating sample size for a pilot test, Julious (2005) suggests a minimum sample size of 12 subjects per treatment arm.

The other instrument is an adapted standardized instrument named the Utrecht Work Engagement Scale (UWES) that helped measure the work engagement of the subjects of this study. Both tests underwent pilot testing to determine whether the instruments were applicable in measuring the variables of the study. As soon as it was deemed applicable, the researchers proceeded with data gathering. After collection, data were analyzed and interpreted. Following that, conclusions and recommendations were made. As mentioned, the aim was that based on the result of the study, a mental health program would be created that would benefit the subjects and other individuals in the future.

The researchers employed a quantitative research design. Specifically, it was a design that involved the administration of a questionnaire to obtain data on the level of psychological distress and level of work engagement among college faculty members.

\section{Results}

The data gathered were then analyzed, interpreted and presented as follows:

\section{Descriptive statistics}

\section{Psychological Distress of Selected UB Faculty Members}

To answer the questions of the study, the researchers gathered data from 50 faculty members who were willing to participate in the study. Each faculty member who participated in the study had to answer the questionnaires online. The descriptive data are presented in the following tables:

Table 1: Level of psychological distress of selected UB faculty members

\begin{tabular}{lccl}
\multicolumn{3}{c}{$\mathrm{n}=50$} \\
\hline $\begin{array}{l}\text { Variable: } \\
\text { Psychological Distress }\end{array}$ & $\mathrm{N}$ & Mean & Standard Deviation \\
\hline Male & 25 & 2.88 & 0.58 \\
Female & 25 & 2.82 & 0.54 \\
Overall & 50 & 2.85 & 0.56 \\
\hline
\end{tabular}

Typical ratings on the level of psychological distress showed a mean of $2.85(S D=0.56)$, indicating a mild level of psychological distress among selected faculty members of the UB. It can also be seen from Table 1 that between male and female faculty members of the UB, male teachers exhibited a higher tendency to feel mild psychological distress, although the difference is not statistically or significantly high. Faculty members in mild psychological distress may exhibit behaviors that do not disrupt others but may indicate something is wrong and assistance is needed (Viertiö et al., 2021). 
Work Engagement of Selected Faculty Members

Table 2: Level of work engagement of selected UB faculty members

\begin{tabular}{|c|c|c|}
\hline $\begin{array}{l}\text { Variable: } \\
\text { Work Engagement }\end{array}$ & Mean & Standard Deviation \\
\hline Males' Work Engagement & 4.75 & 0.69 \\
\hline a. Vigor & 4.71 & 0.85 \\
\hline Dedication & 5.12 & 0.84 \\
\hline Absorption & 4.49 & 0.64 \\
\hline Females' Work Engagement & 4.59 & 0.75 \\
\hline a. Vigor & 4.55 & 0.84 \\
\hline Dedication & 4.84 & 0.84 \\
\hline Absorption & 4.42 & 0.78 \\
\hline Overall Work Engagement & 4.67 & 1.44 \\
\hline a. Vigor & 4.63 & 0.84 \\
\hline Dedication & 4.98 & 0.84 \\
\hline Absorption & 4.45 & 0.71 \\
\hline
\end{tabular}

Typical ratings on level of work engagement items showed a mean of $4.67(S D=1.44)$, indicating a high level of work engagement among selected faculty members of the UB. This means that the faculty members experience a uniquely positive, fulfilling, workrelated state of mind. It can also be seen from Table 2 that between male and female faculty members of UB, male teachers exhibited more work engagement than female members, although the difference is not statistically or significantly high. This is because male members do not have many roles to fulfil, unlike female members who are often engaged in and occupied by other roles or responsibilities at home or in other aspects of their lives (Sparks, 2017).

\section{Inferential statistics}

\section{Significant Relationship in the Level of Psychological Distress and Work Engagement Among Selected Teachers}

Table 3: Relationship between psychological distress and work engagement among selected teachers in UB

\section{Relationship}

\begin{tabular}{lccc}
\hline \multicolumn{1}{c}{ Variable } & Pearson's r & p-value & Significance \\
\hline Psychological Distress - Vigor & -0.56949 & $<0.001$ & Significant \\
Psychological Distress - Dedication & -0.58979 & $<0.001$ & Significant \\
Psychological Distress - Absorption & -0.22017 & 0.125 & Not Significant \\
Psychological Distress - Work Engagement & -0.51494 & $<0.001$ & Significant \\
\hline
\end{tabular}

Note: Pearson's $r$ is significant at $p<0.05$

Table 3 shows that the respondents' psychological distress is significantly correlated with their work engagement $(R=-.0 .51 ; p<.001)$. While the correlation is negative, this indicates that as the respondents' level of work engagement increases, their level of psychological distress decreases. This means that as faculty members' level of distress 
decreases, then their work engagement and productivity at the workplace increase. According to Halvorson (2013), if people can manage distress, then they can work more effectively and perform their tasks. This also means that since the computed probability value is less than the set $\mathrm{p}$-value of 0.05 , the null hypothesis that there is no significant relationship between the level of psychological distress and work engagement among selected faculty members in the UB is rejected.

\section{Significant Difference in the Level of Psychological Distress Among Selected UB Teachers in Terms of Gender \\ Table 4: The difference in the level of psychological distress among teachers in University of Batangas in terms of gender

\begin{tabular}{cccccc}
\hline Variable & t-value & df & t-critical & $\begin{array}{c}\mathrm{p}- \\
\text { value }\end{array}$ & Significance \\
\hline \hline $\begin{array}{c}\text { Psychological } \\
\text { Distress }\end{array}$ & 0.40 & 48 & 1.68 & 0.69 & Not Significant
\end{tabular}

Note: $\mathrm{A}$ - agree, $\mathrm{D}$ - disagree, $\mathrm{N}$ - neither agree nor disagree; $\mathrm{t}$-value is significant at $\mathrm{p}<0.05$

From Table 4 above, it can be seen that no significant difference was found in the level of psychological distress between male and female faculty members of the UB $(20.40=$ $48, p=0.69)$. Therefore it cannot be concluded that female faculty members are more likely to experience higher levels of psychological distress than males and vice versa. These findings imply that whether one is male or female, the level of psychological distress experienced is the same for all. This also means that since the computed probability value is less than the set p-value of 0.05 , the null hypothesis that there is no significant difference in the level of psychological distress among faculty members in UB in terms of their gender is also rejected. This can be true since both males and females are in the same workplace and have same nature of work: that is why they can both experience the same stressors and the same level of psychological distress regardless of gender.

\section{Discussion}

Results in the study of Clipa (2017), showed that when the working conditions, family situation, the social network outside the workplace, and personal characteristics or the stressors people or workers experience were controlled, the level of psychological distress was significantly lower among professional workers. This is the reason why even mild levels of distress experienced by faculty members still need assistance from the responsible personnel such as Guidance Counseling and Health Office and Human Resource Department. Among the working conditions studied, skill utilization, psychological demands, and job insecurity were positively associated with psychological distress levels, whereas social support in the workplace was inversely related to distress.

Moreover, the faculty members' high level of work engagement is demonstrated in the following areas of work engagement, namely vigor $(M=4.63, S D=0.84)$, dedication $(M=4.98, S D=0.84)$ and absorption $(M=4.45, S D=0.71)$. Scores obtained among three categories each indicate that they most often feel engaged in their work. It shows that most UB faculty members exhibit high levels of persistence in their work, 
find meaning in their work and are engrossed in their job and find meaning in the quality of life they have (Fradelos, et.al, 2019).

According to Rynes et, al. (2012), it has been found that the prevention of mental disorders such as depression and the promotion of employees' mental health are both important issues given consideration at workplace since both can influence individual productivity. As a result, numerous employers currently devote substantial resources to promote work engagement, given its positive impact on both productivity and employee health status. Work engagement is a positive, fulfilling, work-related state of mind that is characterized by vigor, dedication, and absorption. Previous studies report that a high levels of work engagement is related to productivity and good mental and physical health (Cirligeanu, 2017).

More specifically, respondents' vigor and dedication also show inverse yet significant association with their level of psychological distress $(R=-.0 .57, p<.001 ; R=-.0 .59$; $p<.001)$. This means that as their level of vigor and dedication increases, their level of psychological distress decreases. Conversely, results revealed that no significant relationship was found between the respondents' level of psychological distress and their area of work engagement called absorption $(R=-.022, p=0.125)$. According to Thorsteinsson et.al (2014), as respondents' sense of dedication at work increases and they are in good health, then their level of psychological distress decreases.

Halvorson (2013) maintained that results which suggest a dual focus on reducing job demands related to burnout and increasing the availability of job resources to enhance work engagement may help combat psychological distress among employees.

Some interventional researches such as the study of Jindo et.al (2019), Mauno \& Ruokolainnen (2007), Gera et.al (2019) all agreed that conducted workplace exercise programs reported a positive effect of the program on the vigor of work engagement. The results also indicate that a higher frequency of workplace exercise is related to higher vigor of work engagement. These studies are consistent with the point of view of a noninterventional study that included a variety of participants (Sparks, 2017).

Recently, research in occupational health has focused on positive mental health outcomes. One such outcome is work engagement, which is a positive, fulfilling, workrelated state of mind and measured with three dimensions: vigor, dedication, and absorption. Also, it was discussed that work engagement was positively associated with the quality of life of employees and productivity and that psychological distress can affect anyone, leading to lower productivity and work engagement in the workplace (Rynes et al., 2012).

\section{Conclusion}

Based on the results of the study, the researchers have come to the conclusion that each faculty member must be assessed once in a while such as annually to determine their level of psychological distress as it affects many aspects of their lives and also their functioning in the workplace. Furthermore, faculty members must continue to participate in activities of the university to maintain their high level of work engagement. Finally, a support program must be developed to aid faculty members who are experiencing mild to severe levels of psychological distress. 


\section{References}

Cîrligeanu, M. (2017). Teacher Stress and Coping Strategies. In O. Clipa (ed.), Studies and Current Trends in Science of Education (pp. 120-128). Suceava, Romania: Lumen Proceedings. https://doi.org/10.18662/lumproc.icsed2017.14

Clipa, O. (2017, June 9-10). Teacher stress and coping strategies. In the Proceedings of the 15th edition of the International Conference on Sciences of Education, Studies and Current Trends in Science of Education, ICSED 2017, (pp. 120-129). Suceava (Romania). https://doi.org/10.18662/lumproc.icsed2017.14

Fradelos, E. C., Kapsiocha, E., Tzavella, F., Kastanidou, S., Tsaras, K., Papagiannis, D., \& Papathanasiou, I. V. (2019). Factors associated with psychological distress in university students and the relation to emotional intelligent and spirituality: A cross-sectional study. Materia Socio-Medica, 31(4), 262-267. https://doi.org/10.5455/msm.2019.31.262-267

Gera, N., Sharma, R., \& Saini, P. (2019). Absorption, Vigor And Dedication:Determinants Of Employee Engagement Inb-Schools. Indian Journal of Economics \& Business, 18(1), 61-70.

Halvorson, H. G. (2013). How you can benefit from all your stress. Psychology Today. http://www.psychologytoday.com/blog/the-science-success/201303/how-you-canbenefit-all-your-stress

Jindo, T., Kai, Y., Kitano, N., Tsunoda, K., Nagamatsu, T., \& Arao, T. (2019). Relationship of workplace exercise with work engagement and psychological distress in employees: A cross-sectional study from the MYLS study. Preventive medicine reports, 17, 101030. https://doi.org/10.1016/j.pmedr.2019.101030

Mauno, S., Kinnunen, U., \& Ruokolainnen, M. (2007). Job demands and resources as antecedents of work engagement: A longitudinal study. Journal of Vocational Behaviour, 70, 149-171.

Julious, S. A. (2005). Sample Size of 12 per Group Rule of Thumb for a Pilot Study. Pharmaceutical Statistics, 4, 287-291. http://dx.doi.org/10.1002/pst.185

Pagayanan, R. P., \& Ed, M. A. M. (2016). Stress profile of public elementary school teachers in Tacloban City Division: Inputs for a proposed classroom intervention program. 2013-2016. https://doi.org/10.17758/uruae.uh0516121

Tan, J. S. T. (2017). Factors affecting stress among faculty members of public universities in the Philippines: A multiple regression analysis. International Journal of Psychological Studies, 9(3), 64. https://doi.org/10.5539/ijps.v9n3p64

Rynes, S. L., Bartunek, J. M., Dutton, J. E., \& Margolis, J. D. (2012). Care and compassion through an organizational lens: Opening up new possibilities. Academy of Management Review, 37(4), 503-523.

Sparks, S. D. (2017). How teachers' stress affects students: A research roundup. Edweek.Org. https://www.edweek.org/tm/articles/2017/06/07/how-teachers-stress-affectsstudents-a-research.html

Viertiö, S., Kiviruusu, O., Piirtola, M., Kaprio,J., Korhonen,T., Marttunen, M., \& Suvisaari, J. (2021). Factors contributing to psychological distress in the working population, with a special reference to gender difference. BMC Public Health 21, 611. https://doi.org/10.1186/s12889-021-10560-y

Thorsteinsson, E. B., Brown, R. F., \& Richards, C. (2014). The Relationship between WorkStress, Psychological Stress and Staff Health and Work Outcomes in Office Workers. Psychology, 5, 1301-1311. http://dx.doi.org/10.4236/psych.2014.510141 


\section{Appendix 1}

\section{Questionnaires}

Name:

Department:

Employment Status:

Gender:

\section{PD Test}

Please be aware that there are no right or wrong answers in this test. Please pick the first answer that comes to your mind and kindly answer the test honestly.

General Direction: Please put a check mark $(\sqrt{ })$ on the corresponding box of your answer per item.

\begin{tabular}{|c|c|c|c|c|c|}
\hline \multicolumn{6}{|c|}{$\begin{array}{l}4 \text { - Strongly Agree } \\
3 \text { - Agree } \\
2 \text { - Disagree } \\
1 \text { - Strongly Disagree }\end{array}$} \\
\hline & $\begin{array}{l}1 \text { - } \\
\text { Strongly } \\
\text { disagree }\end{array}$ & $\begin{array}{l}2- \\
\text { Disagree }\end{array}$ & $\begin{array}{l}\text { 3- Neither } \\
\text { agree nor } \\
\text { disagree }\end{array}$ & $\begin{array}{l}4- \\
\text { Agree }\end{array}$ & $\begin{array}{l}\text { - } \\
\text { Strongly } \\
\text { agree }\end{array}$ \\
\hline $\begin{array}{l}\text { Even if I am very busy at work, I } \\
\text { still have ways to balance my } \\
\text { life.* }\end{array}$ & & & & & \\
\hline $\begin{array}{l}\text { Recently, I have trouble } \\
\text { concentrating on things. }\end{array}$ & & & & & \\
\hline $\begin{array}{l}\text { What I am going through in my } \\
\text { life at present makes it hard for } \\
\text { me to think and act. }\end{array}$ & & & & & \\
\hline $\begin{array}{l}\text { I have been experiencing } \\
\text { problems with sleeping lately. }\end{array}$ & & & & & \\
\hline $\begin{array}{l}\text { Lately, I have been feeling bored } \\
\text { and unsatisfied with how I spend } \\
\text { most of my workday. }\end{array}$ & & & & & \\
\hline $\begin{array}{l}\text { I feel that most of the things that } \\
\text { are happening to me at present } \\
\text { are beyond my control. }\end{array}$ & & & & & \\
\hline
\end{tabular}




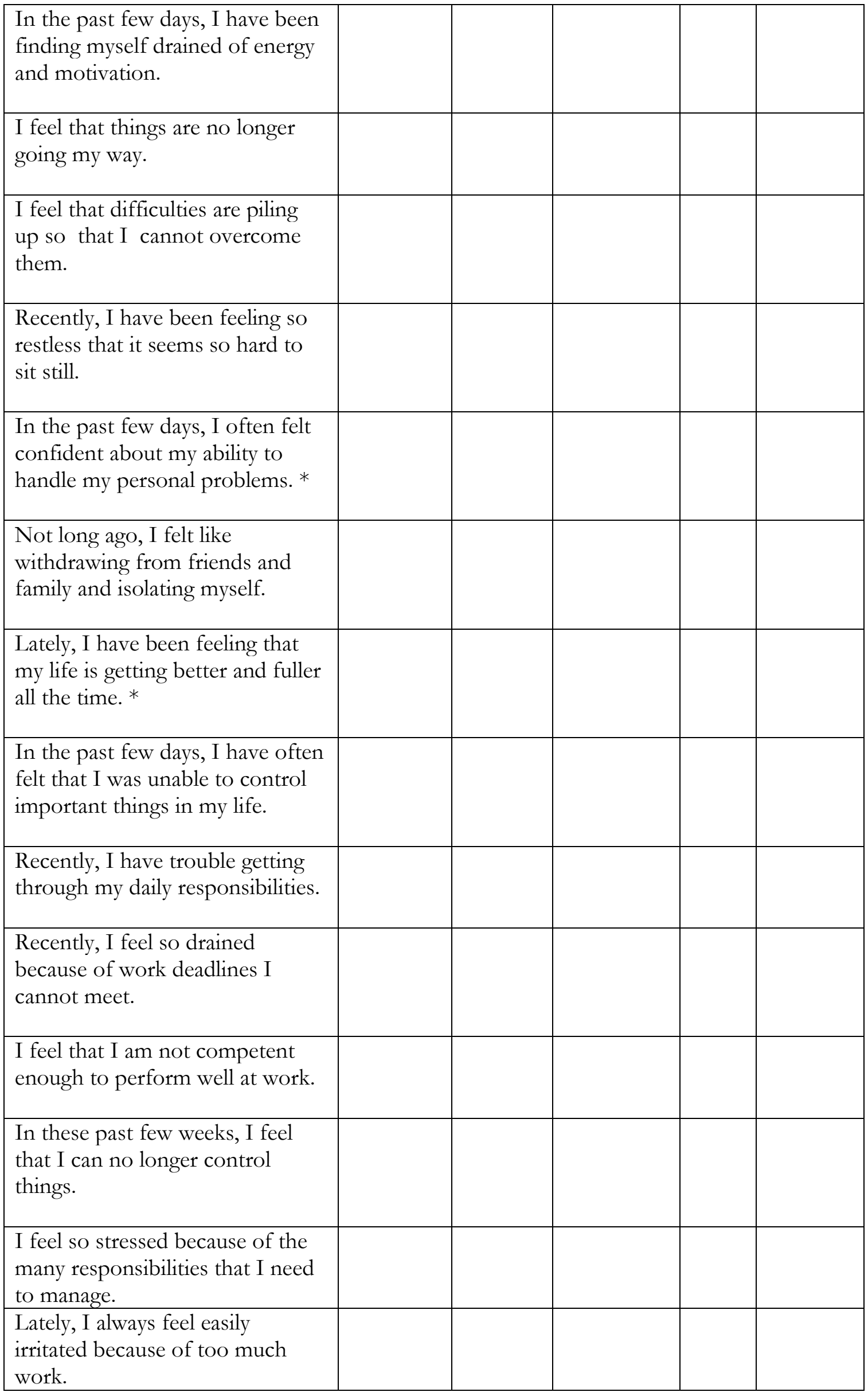




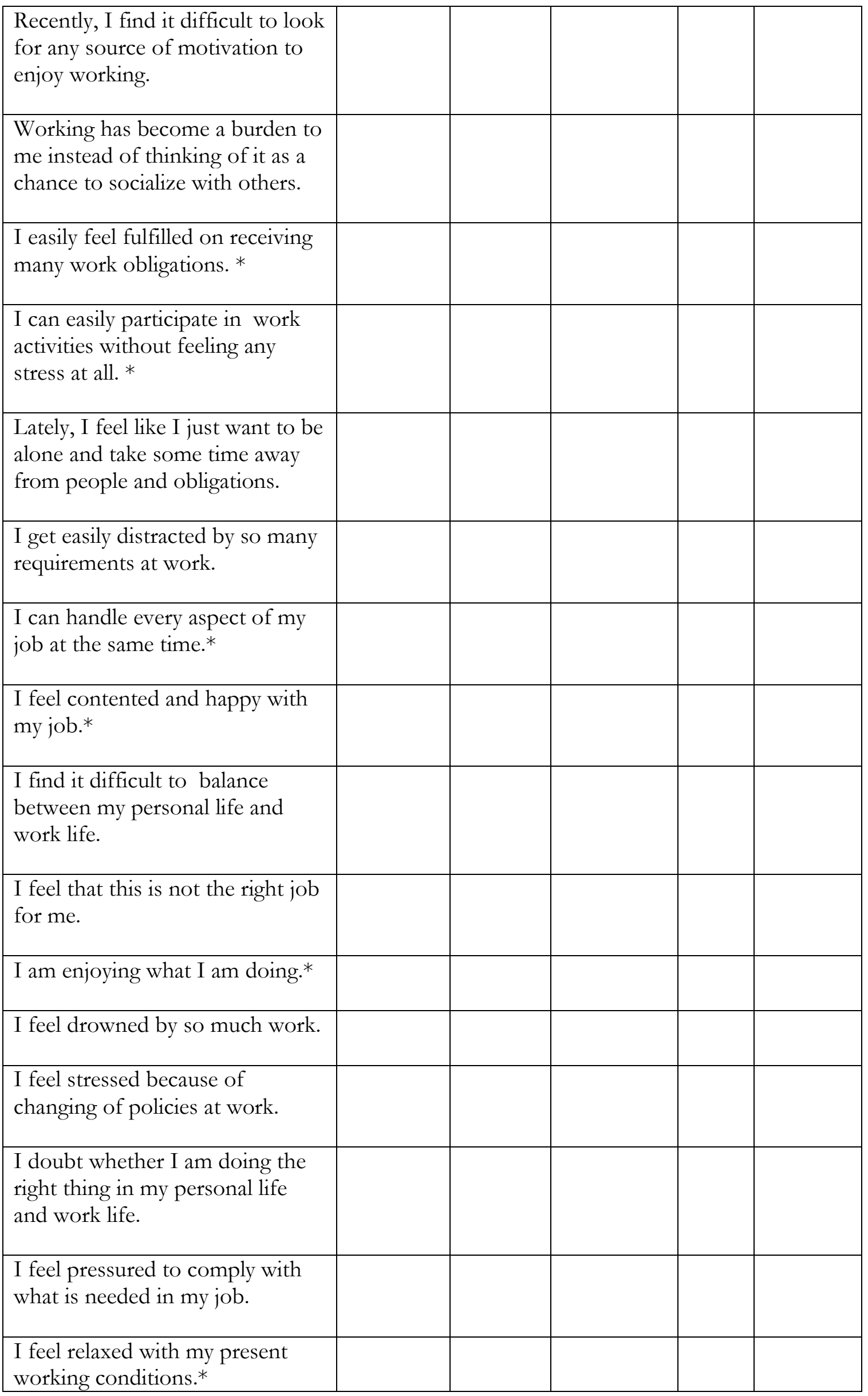




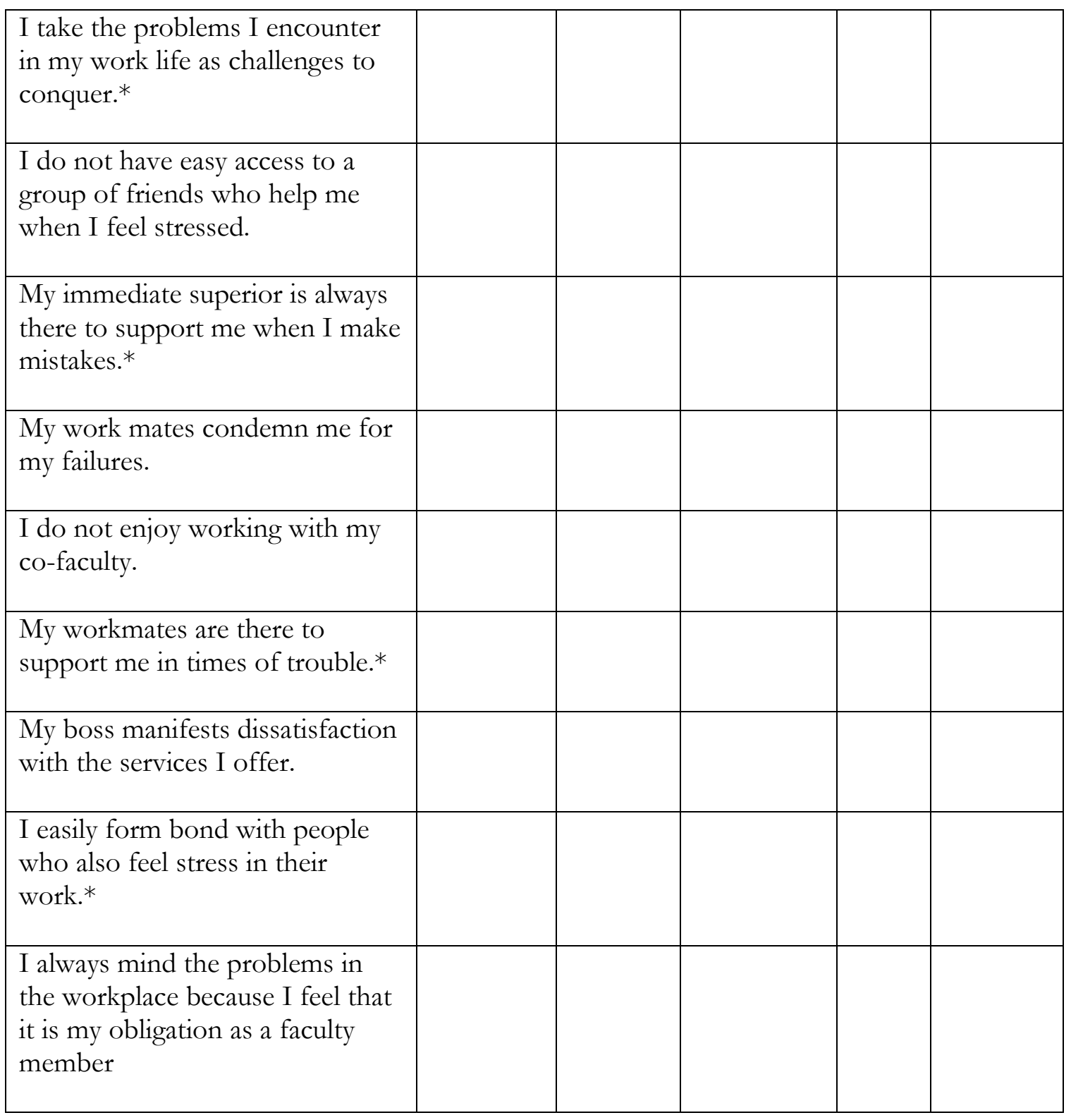

Note: Those with asterisks at the end of some statements are positively worded items. It was decided to include such items so that the consistency of the respondents' answers can be checked or monitored. 


\section{Appendix 2}

Figure 1

Conceptual Framework

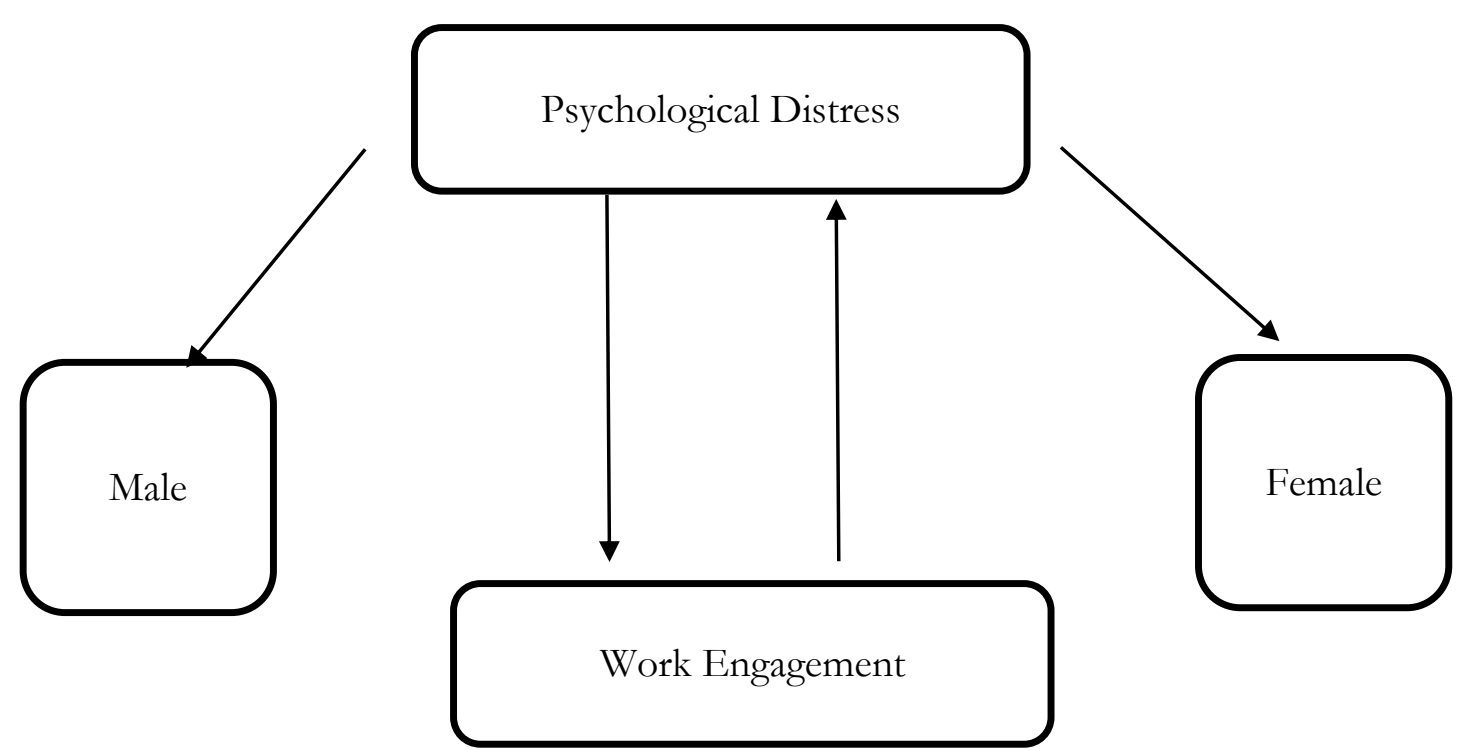

The conceptual framework created shows that psychological distress and work engagement are connected. A person's level of distress has some impact on how he or she functions professionally and personally. Psychological distress also chooses no one: anyone, male or female, can experience distress in their lives and this affects their functioning. With this, hypotheses have been made as psychological distress is required to be differentiated in terms of gender and to show that the level of distress influences the engagement of teachers at work. 


\section{Appendix 3}

\section{Proposed mental health program}

With the findings that faculty members' work engagement is significantly linked with their level of psychological distress, it could therefore be said that a mental health program for faculty members would be beneficial.

A mental health intervention that will help increase their work engagement would be significantly helpful at least in combating the experience of distress among teachers. Likewise, separate activities to aid in reducing psychological distress would also be advantageous. The inclusion of mental health services within school systems would not only result in an improvement of work among teachers but also in their mental health.

A. Suggested activities in reducing psychological distress among faculty members

B. Suggested activities in improving work involvement among faculty members

- Annual assessment of psychological distress

An annual assessment of the psychological distress of each faculty member should be done based on the findings that male or female teachers experience moderate levels of distress. It would be helpful if the Guidance Counseling and Health Office and Human Resource Department know the level of distress and the actions they need to take or programs they need to implement to promote the well-being of each faculty member of the university.

Mindfulness training

Mindfulness training is also necessary since it promotes an optimistic perspective in the life and the welfare of each individual. It was found in the study that owing to different stressors, faculty members can still be affected while working. It is positive that they are highly engaged in their work. The Guidance Counseling and Health Office and Human Resource Department should work together to conduct the required training since the Human Resource Department can easily disseminate information and also assist with the training and seminars faculty members need to attend. This includes the Guidance Counseling and Health Office since they are also knowledgeable enough to provide lectures and to coordinate with speakers or lecturers for effective mindfulness training

Mental health day

This mental health day is a celebration intended to promote mental health awareness, the importance of taking care of mental health and its role on how we can function effectively in our different roles and responsibilities, both personal and professional.

Proposed Plan of Activities

\begin{tabular}{|c|c|c|c|c|c|c|}
\hline $\begin{array}{l}\text { Key Result } \\
\text { Area }\end{array}$ & Objectives & Activities & $\begin{array}{l}\text { Supplement } \\
\text { al Budget }\end{array}$ & Facilitators & $\begin{array}{l}\text { Evaluation/Ou } \\
\text { tcome-Based } \\
\text { Criterion }\end{array}$ & Remarks \\
\hline $\begin{array}{l}\text { Mental } \\
\text { Health } \\
\text { Monit } \\
\text { oring }\end{array}$ & $\begin{array}{l}\text { - To } \\
\text { monitor the } \\
\text { annual level of } \\
\text { psychological } \\
\text { distress } \\
\text { experienced by } \\
\text { faculty members } \\
\text { of the university }\end{array}$ & $\begin{array}{l}\text { Annual } \\
\text { assessment } \\
\text { of } \\
\text { psychologi } \\
\text { cal distress }\end{array}$ & $\begin{array}{l}2000-3000 \\
\text { PHP }\end{array}$ & GCHO & $\begin{array}{l}\text { Annual online } \\
\text { assessment of } \\
\text { psychological for } \\
\text { distress for } \\
\text { faculty members }\end{array}$ & $\begin{array}{l}\text { Annual } \\
\text { monitorin } \\
g \text { of } \\
\text { faculty } \\
\text { members } \\
\text { to be } \\
\text { updated } \\
\text { on the } \\
\text { psychologi } \\
\text { cal distress }\end{array}$ \\
\hline
\end{tabular}




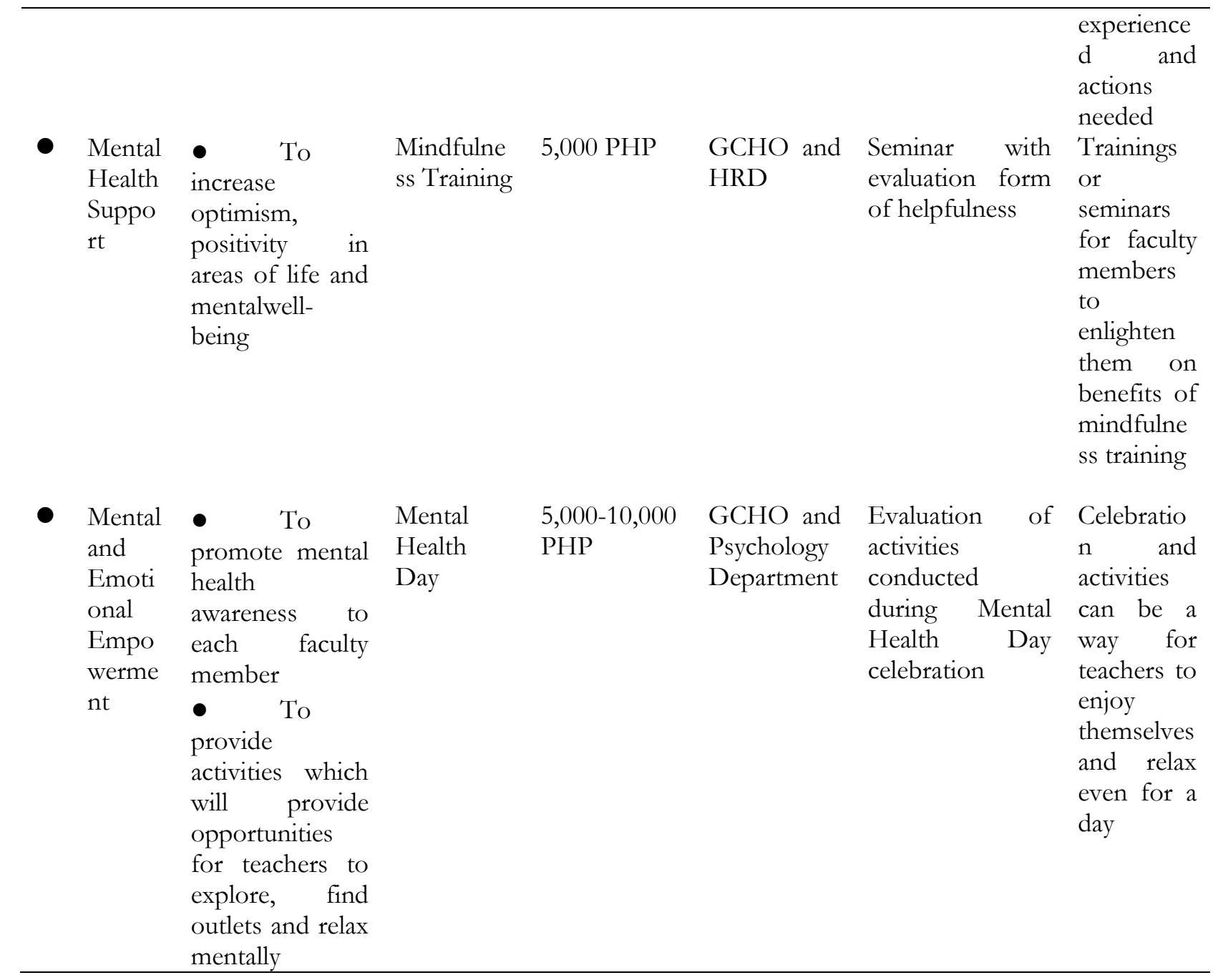

Legend: GCHO- Guidance Counseling and Health Office; HRD-Human Resource Department 